\title{
A new model of two-sown regime for oat forage production in an alpine region of northern China
}

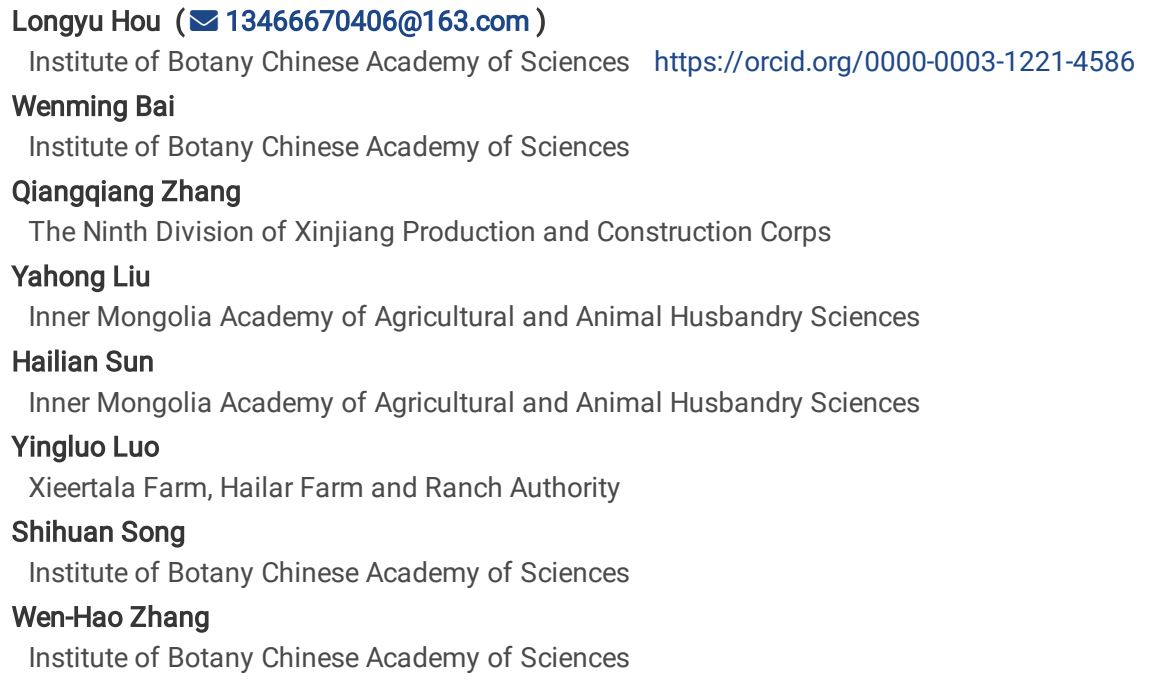




\section{Abstract}

Demand for high forage production and quality of oat (Avena sativa L., A nuda L.) by animal husbandry has increased in recent years, especially in the cold regions of northern China, because these regions are the traditional animal husbandry base. To maximize high quality of forage production, we developed a new model of two-sown regime for oat forage during a single growing season in an alpine region of Hulun Buir, Inner Mongolia Autonomous Region, China, using two early-matured oat species, Avena sativa (cv. Qinghai444, winner oat cultivar) and A. nuda (cv. Huazao2, spring oat cultivar). The key technologies and corresponding mechanisms in the first spring-sown and the second summer-sown were studied by measuring agronomic characteristics and forage quality and production. Furthermore, forage production and quality, resources use efficiency, and economic benefits were compared and quantified between two-sown regime and traditional one-sown regime across three consecutive years (2017-2019). We found that 1 ) the first sowing in spring was done when the thawing depth of soil at 10-13 cm occurred, and the forage yield was mainly achieved by an increase in plant height; 2) The second sowing after harvesting the first sowing oat forage was made in summer under no-tillage treatment, with the yield being mainly due to an increase in tiller density by increasing seeding rate; 3) Compared to traditional one-sown regime, dry weight yield, crude protein yield and relative feed value were significantly increased by $53.6 \%$, $48.9 \%$ and $70.6 \%$ across three experimental years of $2017-2019$, respectively. These results clearly demonstrate that the two-sown regime of oat is an effectively way in improving forage production and quality as well as increasing benefits in an alpine region of northern China.

\section{Introduction}

Oat (Avena Linn.) is an important cereal crop in the world, and represents a major source of forage for livestock around the globe (Fraser and McCartney, 2004; Favre et al., 2019). Oat is mostly grown in cool climate and sensitive to hot, dry weather from head emergence through to maturity, thus oat production is generally concentrated in latitudes from 35 to $65^{\circ} \mathrm{N}$ (Suttie and Reynolds, 2004). Oat has been traditionally planted in cold regions of high latitudes and altitudes as grain for food and feed in China (Tian and Zhang, 2016), and as forage for livestock in recent years (Hou et al., 2021). However, the demand of animal husbandry for oat forage has been increased markedly (Fang et al., 2018; Kuang et al., 2018), as evidenced by rapidly increasing import of oat forage from $0.15 \times 10^{4}$ tons in 2008 to $30.81 \times 10^{4}$ tons in 2017 (Tao et al., 2018), and expanding growth area of oat forage from $5.5 \times 10^{4}$ ha in 2008 to $10.2 \times 10^{4}$ ha in 2015 in China (Hou et al., 2019). In addition, traditional sowing, harvesting regime and corresponding technologies greatly limited oat forage production (Yang et al., 2019). Therefore, it is of significance in developing novel sowing and harvest regime to enhance forage production and quality.

Cold regions accounting for $1 / 3$ areas of the territory are the traditional animal husbandry base in China (Zhang et al., 2018). Their traditional agricultural systems are one crop production of late spring-sown and early autumn-harvested in the regions with frost-free period of $90-125 \mathrm{~d}$ referred to as one-sown regime (Zhou et al., 2018; An et al., 2020). The harvest of oat grain requires growing period from 70 to $120 \mathrm{~d}$ depending on cultivars with early to late maturation (Tian and Zhang, 2016). In contrast, a shorter growing period (from 50 to 80 days) for oat forage production, as the optimal harvested growing stage ahead of grain ripening (Kilcher and Troelsen, 1973; Chapko et al., 1991; Maloney et al., 1999; Steve, 2005; Favre et al., 2019). Furthermore, consecutive cropping of oat in one growing season has proved to be feasible (Chai, 2012; Coblentz et al., 2014). For example, within the same production year, spring-sown followed by autumn-sown oat production strategy is workable in the central Wisconsin (Coblentz et al., 2014). In northern China, consecutive oat planting and harvesting in two years had no negative effect on grain and forage production (Chai, 2012). In addition, the traditional agricultural system is one-crop production in one year and rotates the other crop in next year with no plant covering the soils in non-growing seasons of long winners in cold regions of northern China (Yang et al., 2019; An et al., 2020). In this context, it is feasible to sow oat in summer after harvesting spring-sown oat in these regions. Therefore, we developed a two-sown regime of oat forage, referring to as two-sown regime, based on characteristics of oat growing and forage harvesting, climatic conditions of growing season, continuous cropping of oat in cold regions. Briefly, the regime included sowing oat in spring and harvesting in summer, and thereafter sowing oat again in summer and making harvest in late autumn.

To achieve the two-sown regime, optimizing sowing date in spring is a key, which determined the onset of the oat growing. Previous studies have reported that oat germination and emergence can occur in a relative low temperature of $2 \sim 4^{\circ} \mathrm{C}$, and tolerate to light frosts (Steve, 2005). In addition, sowing in spring as early as possible can improve oat forage production at the middle mountainous area, Korea (Seo et al., 2001). We thus postulate that sowing as early as possible in spring would also improve seedling growth and forage production under limited growing seasons.

Effective soil preparation and optimizing seedling rate may directly determine the output of the second sowing in summer. Firstly, as a long-day plant, oat can joint, elongate and head by sowing in summer, even in autumn in some regions worldwide (Contreras and Albrecht, 2006; Gunsaulis et al., 2008; Coblentz and Walgenbach, 2010; Coblentz et al., 2012). Secondly, sowing as soon as possible after harvesting the spring-sown in summer would allow the oat to fully utilize the nature sources such as temperature, light, precipitation during germination and growing. Previous studies have reported that no-tillage oat sowing can enhance forage production by improving soil nutrients (Wang et al., 2016a), enzymatic activities (Wang et al., 2016b) and soil microbial C, N, P concentrations (Guo et al., 2012). We postulated that no-tillage is a better management practice in second-sown after harvesting the spring-sown oat. Seeding rate has also been suggested to be one of the important factors in improving oat forage production, and increasing seeding rate can enhance oat forage and grain production, especially in hot conditions (Wang 2009; Vinod et al., 2012; Zhao et al., 2016). In addition, previous studies also showed that increasing seeding rate improved forage quality due to a decrease in thickness of stem and an increase in leaf biomass (Contreras and Albrecht, 2006; Xiao et al., 2017). Thus we postulated that increasing seeding rate for the summer-sown oat would increase forage production through increasing tiller density.

In this study, three experiments associated with two-sown regime of oat across three consecutive years in a cold region of northern China were conducted. Specifically, we firstly optimized timing for the first-sown oat in early spring (Experiment 1). We then determined seeding rate in the second-sown oat in summer (Experiment 2). We finally compared yield and quality of oat forage, resource use efficiency and benefit between the two-sown regime and traditional one-sown regime across three constructive years of 2017-2019 (Experiment 3). We further explored the mechanisms underlying the two-sown regime of oat in terms of forage production and quality. 


\section{Materials And Methods}

\subsection{Study site}

The experiments were conducted in Xieertala farm ( $49^{\circ} 11^{\prime}-49^{\circ} 31^{\prime} \mathrm{N}, 119^{\circ} 47^{\prime}-120^{\circ} 18^{\prime} \mathrm{E}$, altitude $\left.612-790 \mathrm{~m}\right)$, the key farm of Hulun Buir State Farm

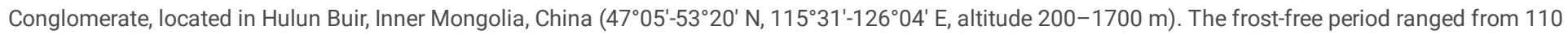
to $125 \mathrm{~d}$, with crop growing season in early-May to middle-August. The mean annual temperature and mean annual precipitation are $-1.3^{\circ} \mathrm{C}$ and $348.4 \mathrm{~mm}$, respectively; the annual accumulated temperature in $\geq 0^{\circ} \mathrm{C}$ and $\geq 10^{\circ} \mathrm{C}$ is $2279-2647^{\circ} \mathrm{C}$ and $1856-2274^{\circ} \mathrm{C}$, respectively (Hou et al., 2021). Soil type is chestnut soil. The basic soils ( $0-20 \mathrm{~cm}$ layer) were sampled prior to sowing in spring and their chemical characteristics were measured: soil pH $6.45 \pm 0.23$, organic matter $31.1 \pm 1.0 \mathrm{~g} \mathrm{~kg}^{-1}$, total $\mathrm{N} 1.82 \pm 0.12 \mathrm{~g} \mathrm{~kg}^{-1}$, inorganic $\mathrm{N} 94.6 \pm 4.5 \mathrm{mg} \mathrm{kg}^{-1}$, available $\mathrm{P} 15.1 \pm 4.5 \mathrm{mg} \mathrm{kg}^{-1}$, and available K $161 \pm 36 \mathrm{mg} \mathrm{kg}^{-1}$.

The dynamic change in monthly precipitation and mean monthly temperature exhibited a single-peaked curve in growing season of Apr. to Sep. in experiment year and 30-yr mean (Fig.S1). Compared to the 30-yr mean of the total precipitation (310.6 mm), year of 2018 (326.2 mm) and 2019 (295.0 mm) are normal, while year of $2017(117.6 \mathrm{~mm})$ is dry year. For each growing season, the temperature and precipitation in the early growing season (Apr. to Jun.) were lower than those in the later growing season (Jul. to Sep.) (Fig. S1).

\subsection{Experimental design}

Insufficient high quality forage is a key limited factor in sustainable development of animal husbandry in cold regions of northern China (Zhang et al., 2018). Thus, development novel plant and harvest regime in forage production is an effective way to solve the problems. Based the relative short duration in oat forage production and oat quickly germination and could elongation in summer sowing (See introduction; Tian and Zhang, 2016; Zhou et al., 2018), we developed a two-sown regime of oat in short growing season with long cold winner in northern China shown in Fig. 1. In the two-sown regime, two key technologies were developed and evaluated. In the experiment 1 , sowing at varying dates was conducted. In the experiment 2 , different the sowing regimes were done in second summer-sown. Finally, in the third experiment, the forage yield and quality, resource use efficiency and economical income in two-sown regime were assessed relative to traditional one-sown regime in consecutive growing seasons of 2017-2019 (Table 1).

\subsubsection{Experiment 1: Optimization of sowing date determination in the first spring sown}

Sowing in spring as early as possible can advance the start of growing season. However, the optimal sowing date may be determined by both environmental conditions and crop growing characters. In 2017, a randomized block design with four replicates was conducted to study the effect of sowing date (every10 days from 1 Apr. to 20 May) in early-spring on oat germination and emergence, agronomic characteristics and forage qualities in Xieertala farm. Each plot was $4 \mathrm{~m} \times 5 \mathrm{~m}$. The thawing depth in soil was measured (Table S1). Oat cultivar of A. sativa cv. Qinghai444 (abbreviated as QH444), an early-maturation cultivar widely planted as forage and grains in cold regions of northern China was used (Zhou et al., 2018). The soil was ploughed in the autumn of previous year with oil crop of rape (Brassica campestris). Oat seeds were sown with a row space of $15 \mathrm{~cm}$, depth of $5 \mathrm{~cm}$ in soil, seeding rate at $225 \mathrm{~kg}^{-1}$ and mixture base fertilizers of $42 \mathrm{~kg} \mathrm{~N}, 24 \mathrm{~kg} \mathrm{P}, 24 \mathrm{~kg} \mathrm{~K}$ per hectare were applied.

\subsubsection{Experiment 2: Effects of soil regimes and seeding rate on forage production and quality in the second summer sowing}

Traditionally, oat was sown in the spring soils that were plagued and raked in the previous autumn in northern China (Tian and Zhang, 2016). Soil tillage was affected by weather and soil moisture, which would delay the sowing in summer, and it has been suggested that seedling rate should be increased by $20 \%$ for late planting under warm conditions (DAFF, 2015). Thus, we conducted a split-plot experiment to compare the effects of soil regimes and seeding rates in summer sowing. Main plots were the soil regimes (tillage vs no-tillage) and subplots were the seeding rates $\left(210,225,240 \mathrm{~kg} \mathrm{ha}^{-1}\right)$ with subplot unit of $4 \mathrm{~m} \times$ $5 \mathrm{~m}$ for four replications (Table S2). Oat cultivar of $A$. nuda vs. Huazao2 (HZ2), an early-maturation cultivar also widely planted as forage and grains in cold regions of northern China was used (Tian and Zhang, 2016). The oat seeds were sown with a row space of $15 \mathrm{~cm}$, depth of $3 \mathrm{~cm}$ in soil, and mixture base fertilizers of $18 \mathrm{~kg} \mathrm{~N}, 23 \mathrm{~kg}$ P per hectare were applied. Previous studies indicated that shallower planting can ensure more rapid emergence and early seedling establishment (Steve, 2005). We thus adopted to sow the oat seeds at $3 \mathrm{~cm}$ depth rather than the traditionally sowing at 5-6 $\mathrm{cm}$ depth in spring-sown.

\subsubsection{Experiment 3: Comparison in forage production, resource use efficiency and economical income between two-sown regime and one-sown regime}

On the basis of results obtained from the experiment 1 and experiment 2, the two-sown regime was demonstrated in field conditions, and the traditional onesown regime was considered as controls. Forage yield and quality were determined. The corresponding resource use efficiency and economical income were calculated. In 2017, the data were the optimal combination of experiment 1 (sowing date of 20 April) and experiment 2 (no-tillage and seedling rate of $240 \mathrm{~kg}$ $\mathrm{ha}^{-1}$ ) for the two-sown regime. In 2018 and 2019, the data were measured in fixed four experiment plots (10 $\mathrm{m} \times 10 \mathrm{~m}$ for each) in a large area of about 40 ha demonstration plot in the two-sown regime and one-sown regime, respectively. The details in sowing and management were shown in the Table 2.

Table 2

\begin{tabular}{|lllll|}
\hline Exp. \# & Design & Cultivars & Water regime & Year \\
\hline 1 & The optimum date of spring-sown & Avena sativa cv. Qinghai444 (QH444) & Irrigated & 2017 \\
\hline 2 & The technology in summer-sown & Avena nuda cv. Huazao2 (HZ2) & Irrigated & 2017 \\
\hline 3 & Two-sown regime vs One-sown regime & QH444 + HZ2 & Irrigated & $2017-2019$ \\
\hline Experiment 3: Sowing and management of oat in growing season of year 2017-2019. & & \\
\hline
\end{tabular}

Page 3/14 


\subsection{Measurement and calculation of indexes}

Plant height $(\mathrm{PH})$ was determined with arithmetic average of measuring randomly-selected ten main tillers in each plot.

Tiller density (TD) was calculated as mean tiller number $\left[\left(\mathrm{No}\right.\right.$. $\left.(\mathrm{m} \cdot \mathrm{row})^{-1}\right] \times 6$ (rows), as 6 rows in $1 \mathrm{~m} \times 1 \mathrm{~m}$ quadrat. Mean tiller number was arithmetic average of 3 sections in each plot (Yang et al., 2019).

Dry weight of aboveground biomass (DW) was determined by drying fresh weight at $80^{\circ} \mathrm{C}$ for $48 \mathrm{~h}$ in an oven, and scaled up to $1 \mathrm{ha}$. The fresh weight was cut at a 10 -cm stubble height with a $1 \mathrm{~m} \times 1 \mathrm{~m}$ quadrat.

Crude protein concentrations (CP, \%) were estimated by $\mathrm{CP}=$ total nitrogen $\times 6.25$ as described by Silva et al. (2013). Total nitrogen contents were measured by Kjeltec2200 (FossTM2200, Denmark).

NDF and ADF were determined following the protocols of Nie et al. (2009). Relative feed value (RFV) is calculated as following protocols described by Rohweder et al. (1978):

$\mathrm{RFV}=\mathrm{DDM} \% \times \mathrm{DMI} \% \times 0.775$

$\mathrm{DDM}=88.9-(0.77 \times \mathrm{ADF} \%)$

DMI=(120/NDF\%)

where DDM is digestible dry matter expressed by \% of dry matter, and DMI is dry matter intake expressed by \% of animal body weight.

Crude protein yield $\left(\mathrm{CP}\right.$ yield, $\left.\mathrm{t} \mathrm{ha}^{-1}\right)=\mathrm{CP}(\%) \times \mathrm{DW}$ yield $\left(\mathrm{t} \mathrm{ha}^{-1}\right)$.

Relative feed value yield $(\mathrm{RFV}$ yield, $/ \mathrm{ha})=\mathrm{RFV} \times \mathrm{DW}$ yield $\left(\mathrm{t} \mathrm{ha}{ }^{-1}\right)$

Oat growing days $=$ the harvest date - the emergence date .

Water use efficiency (WUE, kg mm ${ }^{-1}$ ) = DW yield / (Precipitation + irrigation) (Hu et al., 2019).

$\mathrm{N}$ fertilizer use efficiency (FUE, $\left.\mathrm{kg} \mathrm{kg}^{-1}\right)=\mathrm{CP}$ yield $\left(\mathrm{kg} \mathrm{ha}^{-1}\right)$ / Fertilizer $\mathrm{N}$ application $\left(\mathrm{kg} \mathrm{ha}^{-1}\right)$. (St. Luce et al., 2020).

Gross income $\left(\right.$ US $\left.\$ \mathrm{ha}^{-1}\right)=$ Forage price $\left(\mathrm{USS}^{-1}\right) \times \mathrm{DW}$ yield $\left(\mathrm{t} \mathrm{ha}^{-1}\right)$

Gross cost $\left(\right.$ US $\left.\$ \mathrm{ha}^{-1}\right)=$ Cost of seed + Fertilizer + mechanical operation (Rotary tillage prior to the first spring sown, sowing, irrigation, cutting and harvesting, transport, depreciation of machinery)

Net income $\left(\right.$ US\$ ha $\left.{ }^{-1}\right)=$ Gross income - Gross cost

Increased percentage of Indexes of two-sown regime over one-sown regime (IP, \%) = (Indexes of two-harvest regime - Indexes of one-sown regime) / (Indexes of one-sown regime) $\times 100$

Where the Indexes include dry weight yield, crude protein yield, relative feed value yield, growing days, water use efficiency, $\mathrm{N}$ fertilizer use efficiency, gross income and net income.

In the first spring sowing, the Z-score was used to compare the change trend in agronomic characteristics (PH, TD), forage qualities (CP, NDF, ADF, RFV), and yields (DW yield, CP yield, RFV yield) under different sowing date treatments. The Z-score is the number of standard deviations a given data point lies from the mean. Z-core was calculated as

Z-score $=(x-\mu) / \sigma$

Where $x$ is measured value (original value), $\mu$ is the mean of all data in each index, $\sigma$ is standard deviation of all data in each index.

\subsection{Data statistical analysis}

Firstly, all data were tested for normality and homogeneity prior to statistical analysis, and thereafter were log-transformed when necessary. One-way ANOVA was used to evaluate the effects of sowing date on measured and calculated indexes in the first sown of the two-sown regime (Exp. 1). The data collected in the second-sown were analyzed by a general lineal model with different soil regimes and seeding rates as fixed factors and the field blocks $(n=4)$ as random factors (Exp. 2). Two-way ANOVA was used to evaluate the effects of year (2017-2019) and sown regime (two-sown regime, one-sown regime) on forage production and quality, resource use efficiency index, and economic indexes (Exp.3). Multiple comparisons of means among treatments in the first and second sown were conducted by Duncan's multiple range test at $P<0.05$, respectively. Furthermore, the correlation between variables was evaluated using the Pearson's correlation coefficient test for the first-sown and second sown, respectively. Based on the Pearson's correlation, structural equation modelling (SEM) was used to analyze the corresponding mechanism that forage yield through growing characteristics and forage qualities as affected by sowing date in the first sowing and by soil regimes and seeding rate in the second sowing, respectively. Amos (version 22.0.0, Amos Development Corporation, Chicago, USA) was used to parameterize the SEM model. The Statistical Product and Service Solutions (SPSS 21.0; SPSS, Chicago, Illinois, USA) was used to perform the 


\section{Results}

3. Results

\subsection{Experiment 1: Effects of sowing date on forage yield and quality of the first spring- sown}

Except tiller density $(P=0.939)$, sowing date had significant effects on all indexes of agronomic characters, forage qualities and yields (Table 3 , all $P<0.001)$. The highest values for dry weight yield, crude protein yield and relative feed value yield were observed for those sowing date at 10-30 April, 20-30 April and 20-30 April, respectively (Table 3). The Z-score results showed that sowing at 20-30 April had higher yield in dry weight, crude protein and relative feed value with the corresponding thawing depth of soil at 10-13 cm (Fig. 2a). As sowing date delayed, similar to the three yield indexes, the dynamic change in plant height showed a unimodal curve, while the forage quality related indexes including crude protein and relative feed value decreased, but increases in NDF and ADF were detected (Fig. 2b-c).

Table 3

\begin{tabular}{|c|c|c|c|c|c|c|c|c|c|}
\hline \multirow[b]{2}{*}{ Year } & \multirow[b]{2}{*}{$\begin{array}{l}\text { Sowing } \\
\text { regime }\end{array}$} & \multicolumn{4}{|c|}{ The first sowing (Spring-sown) } & \multicolumn{4}{|c|}{ The second sowing (Summer-sown) } \\
\hline & & $\begin{array}{l}\text { Sowing } \\
\text { date }\end{array}$ & $\begin{array}{l}\text { Emergence } \\
\text { date }\end{array}$ & $\begin{array}{l}\text { Harvest } \\
\text { date }\end{array}$ & $\begin{array}{l}\text { Growing } \\
\text { stage }\end{array}$ & $\begin{array}{l}\text { Sowing } \\
\text { date }\end{array}$ & $\begin{array}{l}\text { Emergence } \\
\text { date }\end{array}$ & $\begin{array}{l}\text { Harvest } \\
\text { date }\end{array}$ & Growing stage \\
\hline \multirow[t]{2}{*}{2017} & Two-sown & 20 Apr. & 7 May. & 27 Jun. & GS68 & 30 Jun. & $7 \mathrm{Jul}$. & 12 Sep. & GS73 \\
\hline & One-sown & 11 May. & 21 May. & 20 Aug. & GS92 & & & & \\
\hline \multirow[t]{2}{*}{2018} & Two-sown & 24 Apr. & 6 May. & 24 Jun. & GS72 & 27 Jun. & 4 Jul. & 12 Sep. & GS69 \\
\hline & One-sown & 11 May. & 20 May. & 29 Jul. & GS92 & & & & \\
\hline \multirow[t]{2}{*}{2019} & Two-sown & 25 Apr. & 7 May. & 27 Jun. & GS65 & 30 Jun. & $8 \mathrm{Jul}$. & 13 Sep. & GS68 \\
\hline & One-sown & 12 May. & 24 May. & 23 Aug. & GS92 & & & & \\
\hline
\end{tabular}

Experiment 1: Agronomic characters, forage quality and yield among different spring-sown date in 2017. PH, plant height; TD, Tiller density; CP, crude protein; NDF, Neutral detergent fiber; ADF, Acid detergent fiber; RFV, relative feed value.

The three yield indexes were significantly correlated to plant height (all $P<0.01$ ), while no significant correlation between the indexes and tiller density was detected (Fig. 3a, all $P>0.05$ ). Crude protein was negatively correlated with NDF and ADF, but it was positively correlated with relative feed value (Fig. 3a, all $P$ $<0.01)$. SEM model revealed that sowing at early dates enhanced dry weight yield $\left(R^{2}=0.890\right)$ by increasing plant height $\left(R^{2}=0.774\right)$, increased relative feed value yield $\left(R^{2}=0.984\right)$ by increasing dry weight yield and relative feed value $\left(R^{2}=0.962\right)(F i g$. 3b). Though earlier sowing significantly increased crude protein $\left(R^{2}=0.953\right)$, but the crude protein yield was not linearly correlated to the change in crude protein (Fig. 3b).

\subsection{Experiment 2: Effects of soil regimes and seeding rate on forage yield and quality of summer-sown oat}

Soil regimes had no significant effects on all those of agronomic characters, forage quality and yield indexes (Table $\mathrm{S} 3$, all $P>0.05)$. In contrast, seeding rate had significant effects on tiller density, NDF, relative feed value, dry weight yield, crude protein yield, relative feed value yield (Table S3, all $P<0.05$ ). Seeding rate at $240 \mathrm{~kg} \mathrm{ha}^{-1}$ had significantly higher tiller density, relative feed value, dry weight yield, crude protein yield, relative feed value yield, but it had significantly lower NDF than those other seeding rates (Table 4).

All the three yield indexes were positively correlated to tiller density (Fig. 4a, all $P<0.01$ ). Crude protein was significantly correlated to crude protein yield ( $\mathrm{r}=$ $0.60, P<0.01)$. Relative feed value had significant relationship with relative feed value yield $(r=0.71, P<0.01)$. SEM model indicated that high seedling rate increased dry weight yield $\left(R^{2}=0.530\right)$ by increasing tiller density $\left(R^{2}=0.425\right)$, increased relative feed value yield $\left(R^{2}=1.000\right)$ by increasing dry weight yield and relative feed value $\left(R^{2}=0.212\right)$. An increase in seeding rate led to increased crude protein $\left(R^{2}=0.242\right)$ by increasing tiller density $($ Fig. $4 \mathrm{~b})$.

\subsection{Experiment 3: the yield, resource use efficiency and profits in two-sown regime}

Compared to one-sown regime, dry weigh yield, crude protein yield and relative feed value yield were significantly increased by $46.8 \%-66.4 \%, 37.1 \%-66.3 \%$ and $63.4 \%-87.6 \%$ in the two-sown regime across three consecutive years of 2017-2019, respectively (Table 5).

Year, sowing regime and their interaction all had significant effects on water use efficiency and $\mathrm{N}$ fertilizer use efficiency (Table 5, all $P<0.001$ ). Compared to one-sown regime, oat growing days were increased by (27-47 days) $29.7 \%-65.3 \%$, water use efficiency increased by $2.2 \%-35.6 \%$, $\mathrm{N}$ fertilizer use efficiency was increased by $-4.1 \%-16.4 \%$ in two-sown regime across year of $2017-2019$, respectively (Table 5).

Two-way ANOVA showed that year, sowing regimes had significant effects on gross income and net income (Table 5, all $P<0.001)$. Compared to one-sown regime, gross income was increased by $57.0 \%-78.1 \%$, net income was increased by $48.0 \%-73.7 \%$ in two-sown regime across experiment year of $2017-2019$, respectively (Table 5). 


\section{Discussion}

In the traditional one-crop production regions in northern China, we developed a two-sown regime for oat forage production (Fig. 1). In the regime, we firstly demonstrated that the first spring-sown was done when the thawing depth of soil at 10-13 cm occurred in early spring (Fig. 2, Table 3). We further found that a higher seeding rate was essential for the second summer-sown after harvesting the spring-sown oat forage under no-tillage (Table 4). Based on consecutive experiments across the three years (2017-2019), compared to the traditional one-sown regime, our results revealed that oat forage yield and quality were significantly increased in the two-sown regime (Table 5). In addition, we demonstrated the regime significantly enhanced water and $\mathrm{N}$ fertilizer use efficiency, as well as the increased net income due mainly to extension of oat growing period (Table 5). These findings highlight that the two-sown regime of oat forage is a promising farming practice to produce more oat forage per unit area with great economic profit and high resource use efficiency in the cold regions.

\subsection{Oat forage yield and its driving factors in first spring-sown of two-sown regime}

Our results demonstrated that spring-sown oat at thawing depth of 10-13 cm soil was an optimal condition for higher dry weight yield, crude protein yield and relative feed value yield in the first-sown of the two-sown regime (Table 3 and Fig. 2a). The optimal sowing date is dependent on harvest objective (grain or forage), utilization of limited natural resource (short growing stage, light, temperature, precipitation in rain-fed regions), and environmental factors (cool temperature, hot, drought environment) (Jehangir et al., 2013; Huang et al., 2020; Vitantonio-Mazzini et al., 2020). For instance, sowing in early spring can avoid less favorable conditions of high temperatures in late June to Mid-July in Ohio (Gooding and Lafever, 1991), keep full utilization of optimal growth in early summer in Korea (Han et al., 2018), and reduce crown rust infection (Puccina coronate Corda) in the Canadian prairies (May et al., 2014). In contrast, sowing in late autumn improved forage yield by minimizing summer heat and drought stress in Wisconsin (Coblentz et al., 2011). In the present study, the first sowing date as early as soil thawing at $10-13 \mathrm{~cm}$ depth may maximize utilization of temperature and light in the early spring, and prevent oat germination and emergence from environmental stresses (Fig. 1, Table S1). Soil temperature has been shown to be a key factor in control of oat germination and emergence (Page et al., 2006). Although oat can initiate seed germination at soil temperature of $2-4^{\circ} \mathrm{C}$ (Steve, 2005), freeze-thaw alternation can occur in different soil layers in early spring. When soil thawing depth was less than $10 \mathrm{~cm}$, the alternation of freezing-thawing by temperature fluctuation would damage the germinated oat seeds in soil layer of 5-6 cm, thus imposing negative effects on the subsequent growth. Previous studies indicated that plant density was influenced by environmental and edaphic conditions at the time of oat germination and emergence (May et al., 2014), and that oat seedling would be damaged by temperatures lower than $-3.3^{\circ} \mathrm{C}$ (Maloney et al., 1999).

Plant height was the main driving factor in dry weight yield in the first-sown of the two-sown regime (Fig. 3b). This result is consistent with previous studies that plant height was the main drivers of oat forage in limited growing duration of autumn-sown in Northern Arkansas (Gunsaulis et al., 2008). In the oat plant development progresses, dry weight significantly increased with increasing plant height, especially in stem elongating stage (Irfan et al., 2016), meaning that early-maturated cultivars with taller canopy should be chosen under insufficient growing days (Coblentz et al., 2011).

\subsection{No-tillage and higher seeding rate increasing oat forage yield in summer-sown}

Summer-sown following harvesting spring-sown of oat forage would ensure oat germination, emergence, joint, stem elongation booting and head by extending the growing season (Fig. 1, Table S2), which is in line with previous studies that oat sown in summer and autumn could joint, elongation and head, compared to other cereal crops (e.g., wheat and rye) that often failed to stem elongation (Gunsaulis et al., 2008; Coblentz and Walgenbach, 2010; Coblentz et al., 2012). Similar to other cereal crops, oat is also a long-day plant, requiring at least $12 \mathrm{~h}$ of daylight to flower and head development (Steve, 2005; Coblentz and Walgenbach, 2010). However, compared to other cereals, oat was shorter season in growth period with low accumulative temperature (May et al., 2004), and grew quickly in the vegetative growth (Seo et al., 1994), which can ensure stem elongation in summer-sown and autumn-sown with limited cumulative temperature and short growing season (Steve, 2005; Gunsaulis et al., 2008; Coblentz and Walgenbach, 2010). The characteristics of stem elongation, flowering and heading in summer-sown oat can produce significantly higher dry weight of aboveground biomass relative to those cereals failed to stem elongation (Coblentz et al., 2012). As shown in our results, the summer-sown regime was an effective method in harvesting higher forage production and quality of oat (Table 4).

Our findings showed that no-tillage had no significant effect on the oat indexes in agronomy, quality and yield under synchronous summer-sown, compared to the tillage sowing (Table 4). Several benefits of no-tillage sowing may exist. Firstly, the cost for no-tillage sowing is reduced relative to tillage sowing. Secondly, no-tillage sowing can also save time, thus maximizing the oat growing period. Thirdly, the no-tillage sowing in summer may minimize soil disturbance, thus favoring the summer-sown oat growth. For example, it has been reported that no-tillage planting increased soil moisture (Page et al., 2006; Hao, 2015; Wang et al., 2016c), availabilities of nutrients in soils (Wang et al., 2016a), enzymatic activities in soils (Wang et al., 2016b), and soil microbial C, N, P concentrations (Guo et al., 2012), thus benefiting oat germination, emergence and subsequent seedling growth. In addition, allelopathic compounds released by oat plants can suppress weed growth under no-tillage conditions (Valenzuela and Smith, 2002). Finally, the stubble of previous oat would protect germination and emergence of summer-sown oat from poor climatic conditions (Page et al., 2006). Previous studies also indicated that preserving surface residues tended to synchronize oat emergence, thus facilitating better timing of weed control where residue is present (Page et al., 2006). However, some contrasting results have reported that no-tillage sowing significantly decreased forage yield by decreasing root biomass, plant height, tiller density and leaf area index (Wang, 2014). The decrease in growth was largely due to increased soil bulk density and weed density under no-tillage regime (Wang, 2014; Zhang, 2014). The difference may be accounted for by the environmental conditions and duration of no-tillage. Long-term no-tillage could increase soil compaction, especially in dry rainfed areas (Wang et al., 2014). In our two-sown regime, soil was ploughed in previous autumn, only summer-sown under no-tillage treatment as well as irrigation management (see methods). It has been reported that early autumn-sown produced more forage by increase stem elongation and subsequent growth relative to late autumn-sown (Coblentz and Bertram, 2012; Dar et al., 2014). Therefore, we can conclude that no-tillage summer-sown can improve forage production by extending oat growing time and decrease cost. 
As seeding rate was increased from $210 \mathrm{~kg} \mathrm{ha}^{-1}$ to $240 \mathrm{~kg} \mathrm{ha}^{-1}$, the dry weight yield, crude protein yield, relative feed value yield all reached peak values (Table 4), suggesting that increasing seeding rate benefits forage yield and quality in summer-sown oat, thus strengthening previous results that increasing seeding rate can lead to higher production of forage yield (DAFF, 2015; Zhao et al., 2016). High seeding rates promoted aboveground biomass by increasing tiller density (Fig. 4b), which is in line with previous studies (Wang 2009; Vinod et al., 2012). Under hot conditions in summer, oat contributed less to tillering and quickly growth in height (Gooding and Lafever, 1991). Tiller density is one of the main factors in determining dry weigh yield of oat forage (Ayub et al., 2011). Furthermore, seeding rate also increased crude protein through increasing tiller density and relative feed value of forage (Table 4; Fig. 4b). High seeding rate may also improve the quality of hay by reducing the thickness of stems with increased tiller density and leaf to stem ratio (DAFF, 2015; Xiao et al., 2017). Therefore, the mechanisms underlying the high seeding rate-induced improving yield and quality in summer-sown may be accounted for by increasing tiller density and crude protein and relative feed value through decreasing thickness of stem.

\subsection{The significance in two-sown regime over one-sown regime}

In the cold regions of China, supply of high quality of forage in time and space is a major driving factor in sustainable development of animal husbandry (Fang et al., 2018; Zhang et al., 2018). The forage and crude protein yield, and relative feed value yield were significantly increased in the two-sown regime, compared to one-sown regime, highlighting high output per unit area (Table 5). Furthermore, supply of oat forage in summer and later-autumn in the two-sown regime can also meet the forage demand in time, where summer is a critical period in livestock feeding in the cold regions of northern China (Kuang et al., 2018). The forage harvested in the previous year has run out by the next summer, while natural grasslands can only provide limited forage supply in summer in this region (Kuang et al., 2018). In addition, oat forage production by the two-sown regime can also make less dependence of local animal husbandry on natural grasslands, thus protecting the grasslands from degradation (Fang et al., 2018). Moreover, despite increases in the gross cost associated with seeds, fertilizers, harvests and irrigation, the gross income and net income were significantly increased in the two-sown regime relative to one-sown regime (Table 5).

The oat growing period was significantly extended in the two-sown regime compared to one-sown regime (Fig. 1, Table 5). This means that more natural resources can be used during oat growth. In addition, the prolonged presence of oat in our two-sown regime can also prevent soils from erosion (Gunsaulis et al., 2008; Coblentz and Bertram, 2012), and suppress weeds in the early spring and late autumn (Valenzuela and Smith, 2002, Vinod, 2012). Another advantage of the two-sown regime is enhanced water use efficiency due to extension of oat growing periods, especially vegetative growing stage and increased the water use in early spring and late autumn.

\section{Conclusions}

We developed a two-sown regime for oat forage production in a cold region with long winter of northern China. The first sowing in spring can be done in early spring when soil at $10-13 \mathrm{~cm}$ was thawed. The high yield of oat forage by the first sowing mainly resulted from increases in plant height. The second sowing was done in summer with higher seeding rates under no-tillage regime. The high forage yield was mainly due to the increases in tiller density and seeding rates. Compared to traditional one-sown regime, the dry weight yield, crude protein yield and relative feed value yield were significantly increased by $53.6 \%$, $48.9 \%$ and $70.6 \%$ across three experimental years of $2017-2019$, respectively. Finally, the water use efficiency and N fertilizer use efficiency significantly increased or no significantly change in two-sown regime, compared to one-sown regime. The application of this two-sown regime can lead to great forage supply for the animal husbandry and improve environment for sustainable development in the regions with long, cold winter times.

\section{Declarations}

\section{Ethics approval and consent to participate}

No applicable.

\section{Consent for publication}

No applicable.

\section{Availability of data and materials}

The datasets used and/or analysed during the study are available from the corresponding author on reasonable request.

\section{Competing interests}

The authors declare no competing financial interests.

\section{Funding}

This work was funded by Science and Technology Department of Inner Mongolia Autonomous Region (grant number 2020CG0064, 2021SZD003602).

\section{Author contributions}

Hou L, Bai W and Zhang W conceived and designed the experiments; Hou L, Bai W, Zhang Q, Liu Y, Sun H, Luo Y and Song S performed the experiments; Hou L and Zhang $W$ analyzed the data; Hou $L$ and Zhang W wrote the manuscript. 
We thank all technologist and workers in Xieertala farm and experimental station for their help in oat sowing, management, and harvesting in field experiment.

\section{References}

1. An P, Chen S, Meng L, Jiang L (2020) Determination of standard farming system in cultivated land classification of the third national land survey. $J$ China Agric Univ 25:61-72. https://doi.org/10.11841/j.issn.1007-4333.2020.08.07. (in Chinese with English abstract).

2. Ayub M, Shehzad M, Nadeem M, Pervez M, Muhammad N, Sarwar N (2011) Comparative study on forage yield and quality of different oat (Avena sativa L.) varieties under agroecological conditions of Faisalabad, Pakistan. Afr J Agr Res 06:3388-3391. https://doi.org/10.5897/AJAR11.411

3. Chai J (2012) Effects of crop rotation and continuing on productivity, quality, pests and diseases of oats and soil fertility, Gansu Agricultural University, Lanzhou, China. (in Chinese with English abstract)

4. Chapko LB, Brinkman MA, Albrecht KA (1991) Genetic variation for forage yield and quality among grain oat genotypes harvested at early heading. Crop Sci 31:874-878. https://doi.org/10.2135/cropsci1991.0011183X003100040006x

5. Coblentz W, Bertram M (2012) Fall-grown oat forages: cultivars, planting dates, and expected yields. Focus on forage, vol 14 . no 3 . University of Wisconsin Board of Regents, Madison

6. Coblentz W, Bertram M, Martin NP (2011) Planting date effects on fall forage production of oat cultivars in Wisconsin. Agron J 103:145-155. https://doi.org/10.2134/agronj2010.0350

7. Coblentz W, Jokela W, Bertram M (2014) Cultivar, harvest date, and nitrogen fertilization affect production and quality of fall oat. Agron J 106:2075-2086. https://doi.org/10.2134/agronj13.0436

8. Coblentz W, Walgenbach R (2010) Fall growth, nutritive value, and estimation of total digestible nutrients for cereal-grain forages in the north-central United States. J Anim Sci 88:383-399. https://doi.org/10.2527/jas.2009-2224

9. Contreras F, Albrecht K (2006) Forage production and nutritive value of oat in autumn and early summer. Crop Sci 46:2382-2386. https://doi.org/10.2135/cropsci2005.12.0458

10. DAFF (2015) Forage oat variety guide-Department of Agriculture, Fisheries and Forestry. the State of Queensland

11. Dar N, Singh K, Ahmad D, Sofi J, Bhat M, Kotru R (2014) Influence of dates of Sowing, cultivars and different fertility levels on fodder oat (Avena sativa L.) under temperate conditions of Kashmir valley (India). Range Manag Agrofo 35:51-55. https://doi.org/10.1080/03650340.2013.837219

12. Fang J, Jing H, Zhang W, Gao S, Duan Z, Wang H, Zhong J, Pan Q, Zhao K, Bai W, Li L, Bai Y, Jiang G, Huang J, Huang Z (2018) The concept of grassbased livestock husbandry and its practice in Hulun Buir, Inner Mongolia. Chin Sci Bull 63:1619-1631. https://doi.org/10.1360/N972018-00042 (in Chinese with English abstract).

13. Favre J, Albrecht K, Gutierrez L, Picasso V (2019) Harvesting oat forage at late heading increases milk production per unit of area. Crop Forage Turfgrass Manag 5:1-8. https://doi.org/10.2134/cftm2018.06.0046

14. Fraser J, McCartney. D (2004) Fodder oats in North America. Fodder oats: A world overview. Food and Agriculture Organization of the United Nations, Rome

15. Gooding R, Lafever H (1991) Yield and yield components of spring oat for various planting dates. J Prod Agric 4:382-385. https://doi.org/10.2134/jpa1991.0382

16. Gunsaulis J, Coblentz W, Ogden R, Bacon R, Coffey K, Hubbell D, Skinner J, Akins M, Caldwell J, Lusby K (2008) Fall growth potential of cereal grain forages in northern Arkansas. Agron J 100:1112-1123. https://doi.org/10.2134/agronj2007.0301

17. Guo X, Liu J, Zhang X, Li L, Zhao B, Surya N (2012) Effects of non-tillage on soil microbial C,N and P in plough layer of oat field. Acta Pedol Sin 49:575582. https://doi.org/10.11766/trxb201101050008 (in Chinese with English abstract).

18. Han O, Ku J, Min H, Lee H, Joo Y, Lee S, Oh J, Jung K, Kim S (2018) Effect of sowing and harvest time on forage yield and feed value of spring and fall oats at Youngnam mountain area. J Kor GrassI Forage Sci 38:126-134. https://doi.org/10.5333/KGFS.2018.38.2.126 (in Korean with English abstract)

19. Hao Y (2015) Effect of different tillage methods to weed community and soil's physical characteristics in oat field in the cold and arid area in north Hebei. Hebei Agricultural University, Baoding, China, (in Chinese with English abstract)

20. Hou L, Bai W, Zhang Q, Jiao S, Tang G, Luo Y, Bai R, Song S, Zhang W (2021) Agronomic and economical characterizations of a two-harvest regime for oat forage in cold regions of Northern China. Environ Sci Pollut Res. https://doi.org/10.1007/s11356-021-15369-1

21. Hou L, Zhu Z, Yang j, Ma H, Li q, Tao j, Fan B, Hao J, Yan J, Zhou Q, Bai W (2019) Current status, problems and potentials of forage oat in China. J South Minzu Univ (Nat Sci Ed) 45:248-253. https://doi.org/10.11920/xnmdzk.2019.03.004 (in Chinese with English abstract).

22. Hu C, Sadras V, Lu G, Jin X, Jiaxing X, Ye Y, Yang X, Zhang S (2019) Dual-purpose winter wheat: interactions between crop management, availability of nitrogen and weather conditions. Field Crop Res 241:107579. https://doi.org/10.1016/j.fcr.2019.107579

23. Huang M, Fang S, Cao F, Chen J, Zou Y (2020) Early sowing increases grain yield of machine-transplanted late-season rice under single-seed sowing. Field Crop Res 253:107832. https://doi.org/10.1016/j.fcr.2020.107832

24. Iffan M, Ansar M, Sher A, Wasaya A, Sattar A (2016) Improving forage yield and morphology of oat varieties through various row spacing and nitrogen application. J Anim Plant Sci 26:1718-1724

25. Jehangir I, Khan H, Khan M, Mubarak T, Bhat R, Rasool S, Bhat Z (2013) Performance of oat (Avena sativa L.) as influenced by fertilizer application and cutting management at different sowing dates. BIOINFOLET - A Quarterly Journal of Life Sciences 10:1282-1284 
26. Kilcher M, Troelsen J (1973) Contribution and nutritive value of the major plant components of oats through progressive stages of development. Can J Plant Sci 53:251-256. https://doi.org/10.4141/cjps73-047

27. Kuang W, Yan H, Zhang S, Li X, Bao Z, Ning J, Zhang P, Fan B, Wang S (2018) Forage-livestock status in farms and ranches of ecological grass-animal husbandry construction and allocation model of grain-warp-feed in Hulunbuir Agricultural Reclamation Group. Chin Sci Bull 63:1711-1721. https://doi.org/10.1360/N972017-01144 (in Chinese with English abstract).

28. Maloney T, Oplinger E, Albrecht K (1999) Small grains for fall and spring forage. J Prod Agric 12:488-494. https://doi.org/10.2134/jpa1999.0488

29. May W, Mohr R, Lafond G, Johnston A, Stevenson F (2004) Early seeding dates improve oat yield and quality in the eastern prairies. Can J Plant Sci 84:431-442. https://doi.org/10.4141/P02-157

30. Nie Z, Tremblay G, Belanger G, Berthiaume R, Castonguay Y, Bertrand A, Michaud R, Allard G, Han J (2009) Near-infrared reflectance spectroscopy prediction of neutral detergent-soluble carbohydrates in timothy and alfalfa. J Dairy Sci 92:1702-1711. https://doi.org/10.3168/jds.2008-1599

31. Page E, Gallagher R, Kemanian A, Hao Z, Fuerst E (2006) Modeling site-specific wild oat (Avena fatua) emergence across a variable landscape. Weed Sci 54:838-846. https://doi.org/10.1614/ws-05-142r1.1

32. Rohweder D, Barnes R, Jorgensen N (1978) Proposed hay grading standards based on laboratory analyses for evaluating quality. J Anim Sci 47:747-759. https://doi.org/10.2527/jas1978.473747x

33. Seo S, Kim W, Shin D, Choi G, Park G (2001) Forage yield and nutritive value of spring oats for various cultivars and planting dates at the middle mountain area

34. Silva A, Lira M, Dubeux J, Figueiredo M, Vicentin R (2013) Soil litter stock and fertility after planting leguminous shrubs and forage trees on degraded signal grass pasture. Rev Bras Cienc Solo 37:502-511. https://doi.org/10.1590/S0100-06832013000200021

35. St. Luce M, Lemke R, Gan Y, McConkey B, May W, Campbell C, Zentner R, Wang H, Kroebel R, Fernandez M, Brandt K (2020) Diversifying cropping systems enhances productivity, stability, and nitrogen use efficiency. Agron J 112:1517-1536. https://doi.org/10.1002/agj2.20162

36. Steve F (2005) Drought Advisory Series: Oat Hay and Straw. Washington State University Extension, Washington, DC, USA, EM4918E

37. Suttie J, Reynolds S (2004) Fodder oats: a world overview. Food and Agriculture Organization of the United Nations, Rome

38. Tao J, Hou L, Yang J, Song S, Bai W, Pan Q, Yin S, Hao J, Zhang W (2018) Comparative studies on seed germination characteristics and indicators of oat varieties under salt stress. Pratacul Sci 3:2414-2421. https://doi.org/10.11829/j.issn.1001-0629.2018-0110 (in Chinese with English abstract.

39. Tian C, Zhang B (2016) Practical technology of oats China Agricultural University press, Beijing, China

40. Valenzuela H, Smith J (2002) Common oats (green manure crops). Sustainable Agriculture. SA-GM-5. doi: http://hdl.handle.net/10125/12735

41. Vinod T (2012) Growth and production of oat and rye. Soils, Plant Growth and Crop Production, vol.II. Encyclopedia of Life Support Systems

42. Vitantonio-Mazzini L, Borrás L, Garibaldi L, Pérez D, Gambin B (2020) Management options for reducing maize yield gaps in contrasting sowing dates. Field Crop Res 251:107779. https://doi.org/10.1016/j.fcr.2020.107779

43. Wang L (2009) Effect of different cultivating methods on growth and yield of oat, Inner Mongolia Agricultural University, Huhhot, China. (in Chinese with English abstract)

44. Wang R, Liu J, Zhang Z, Liu H (2016c) Effects of No-tillage with different mulching methods on soil water and temperature in rainfed oats field. J Irrig Drain 35:69-73. https://doi.org/10.13522/j.cnki.ggps.2016.11.013 (in Chinese with English abstract)

45. Wang R, Zhang Z, Liu J, Liu H, Liu J, Wu J (2016a) Effects of No-tillage with mulching on soil nutrient content and microbial biomass in oat field. J Soil Water Conserv 30:183-187,193. https://doi.org/10.13870/j.cnki.stbcxb.2016.04.031 (in Chinese with English abstract).

46. Wang R, Zhang Z, Liu J, Liu H, Zhao B (2016b) Effects of No-tillage with stubble mulch on soil nutrients, soil enzyme activities and oat yield. Crops, pp 134-138. https://doi.org/10.16035/j.issn.1001-7283.2016.03.025 (in Chinese with English abstract).

47. Wang Y (2014) The influence of tillage methods on naked oats growth and soil properties in cold and arid regions of north Hebei, Heibei Agricultural University, Baoding. (in Chinese with English abstract)

48. Xiao X, Zhou Q, Chen Y, Du Z, Bai X, Tian L, Peng X (2017) Effect of seedling rate on production performance and photosyntheric characteristics of Avena sativa cv. LINA in alpine pastoral regions. Pratacul Sci 34:761-771. https://doi.org/10.11829/j.issn.1001-0629.2016-0364 (in Chinese with English abstract)

49. Yang J, Hou L, Bai W, Yan J, Hao J, Tao J, Luo Y, Zhang J, Zhang W (2019) A Dual-purpose model for spring-sown oats in cold regions of Northern China. Agronomy 9:721. https://doi.org/10.3390/agronomy9110721

50. Zhang L, Zhang L, Wu D, Zhang J (2014) Effect of tillage patterns on the structure of weed communities in oat fields in the cold and arid region of North China. Ying yong sheng tai xue bao = The journal of applied ecology 25:1725-1732. https://doi.org/10.13287/j.1001-9332.20140415.005 (in Chinese with English abstract).

51. Zhang W, Hou L, Yang J, Song S, Mao X, Zhang Q, Bai W, Pan Q, Zhou Q (2018) Establishment and management of alfalfa pasture in cold regions of China. Chin Sci Bull 63:1651-1663. https://doi.org/10.1360/N972017-01181 (in Chinese with English abstract).

52. Zhao H, Ma Z, Zhang C, Lei Z, Yao B, Zhou H (2016) The reproductive allocation of Arena sativa under different planting densities and nitrogen addition treatments. Pratacul Sci 33:249-258. https://doi.org/10.11829/j.issn.1001-0629.2015-0361 (in Chinese with English abstract).

53. Zhou Q, Gou X, Tian L, Chen Y, Gao S, Bai W, Zhang W (2018) Performances of early and late maturing oat varieties in cold regions. Chin Sci Bull 63:1722-1730. https://doi.org/10.1360/N972018-00343 (in Chinese with English abstract).

\section{Tables}


Table 1

Experimental design and cultivars used to develop two-sown regime of oat.

\begin{tabular}{lllll} 
Exp. \# & Design & Cultivars & Water regime & Year \\
\hline 1 & The optimum date of spring-sown & Avena sativa cv. Qinghai444 (QH444) & Irrigated & 2017 \\
\hline 2 & The technology in summer-sown & Avena nuda cv. Huazao2 (HZ2) & Irrigated & 2017 \\
\hline 3 & Two-sown regime $v$ s One-sown regime & QH444+HZ2 & Irrigated & $2017-2019$
\end{tabular}

\section{Table 2}

Experiment 3: Sowing and management of oat in growing season of year 2017-2019.

\begin{tabular}{|c|c|c|c|c|c|c|c|c|c|}
\hline \multirow[b]{2}{*}{ Year } & \multirow[b]{2}{*}{$\begin{array}{l}\text { Sowing } \\
\text { regime }\end{array}$} & \multicolumn{4}{|c|}{ The first sowing (Spring-sown) } & \multicolumn{4}{|c|}{ The second sowing (Summer-sown) } \\
\hline & & $\begin{array}{l}\text { Sowing } \\
\text { date }\end{array}$ & $\begin{array}{l}\text { Emergence } \\
\text { date }\end{array}$ & $\begin{array}{l}\text { Harvest } \\
\text { date }\end{array}$ & $\begin{array}{l}\text { Growing } \\
\text { stage }\end{array}$ & $\begin{array}{l}\text { Sowing } \\
\text { date }\end{array}$ & $\begin{array}{l}\text { Emergence } \\
\text { date }\end{array}$ & $\begin{array}{l}\text { Harvest } \\
\text { date }\end{array}$ & Growing stage \\
\hline \multirow[t]{2}{*}{2017} & Two-sown & 20 Apr. & 7 May. & 27 Jun. & GS68 & 30 Jun. & $7 \mathrm{Jul}$. & 12 Sep. & GS73 \\
\hline & One-sown & 11 May. & 21 May. & 20 Aug. & GS92 & & & & \\
\hline \multirow[t]{2}{*}{2018} & Two-sown & $24 \mathrm{Apr}$. & 6 May. & 24 Jun. & GS72 & 27 Jun. & 4 Jul. & 12 Sep. & GS69 \\
\hline & One-sown & 11 May. & 20 May. & 29 Jul. & GS92 & & & & \\
\hline \multirow[t]{2}{*}{2019} & Two-sown & 25 Apr. & 7 May. & 27 Jun. & GS65 & 30 Jun. & 8 Jul. & 13 Sep. & GS68 \\
\hline & One-sown & 12 May. & 24 May. & 23 Aug. & GS92 & & & & \\
\hline
\end{tabular}

\section{Table 3}

Experiment 1: Agronomic characters, forage quality and yield among different spring-sown date in 2017. PH, plant height; TD, Tiller density; CP, crude protein; NDF, Neutral detergent fiber; ADF, Acid detergent fiber; RFV, relative feed value.

\begin{tabular}{|c|c|c|c|c|c|c|c|c|c|}
\hline \multirow{3}{*}{$\begin{array}{l}\text { Sown } \\
\text { date }\end{array}$} & \multicolumn{2}{|c|}{ Agronomic characteristics } & \multicolumn{4}{|c|}{ Forage qualities } & \multicolumn{3}{|l|}{ Yields } \\
\hline & $\mathrm{PH}$ & TD & $\mathrm{CP}$ & NDF & ADF & RFV & DW yield & $\mathrm{CP}$ yield & RFV yield \\
\hline & $(\mathrm{cm})$ & $\left(\right.$ No. $\left./ m^{2}\right)$ & $(\%)$ & $(\%)$ & $(\%)$ & & $\left(\mathrm{tha}^{-1}\right)$ & $\left(\mathrm{t} \mathrm{ha}^{-1}\right)$ & $\left(\mathrm{ha}^{-1}\right)$ \\
\hline 1Apr. & $100 \pm 2 b$ & $698 \pm 17 a$ & $10.8 \pm 0.3 d$ & $56.3 \pm 0.6 a$ & $32.9 \pm 0.9 a$ & $105 \pm 0 e$ & $8.84 \pm 0.15 b$ & $0.95 \pm 0.03 c$ & $924 \pm 16 c$ \\
\hline 10Apr. & $104 \pm 2 a b$ & $702 \pm 8 a$ & $11.0 \pm 0.3 d$ & $55.8 \pm 0.7 a$ & $31.6 \pm 0.9 b$ & $107 \pm 1 e$ & $9.72 \pm 0.23 a$ & $1.07 \pm 0.06 b$ & $1042 \pm 27 b$ \\
\hline 20Apr. & $105 \pm 4 a$ & $701 \pm 17 a$ & $11.6 \pm 0.3 c$ & $53.1 \pm 0.9 b$ & $31.1 \pm 0.6 b$ & $113 \pm 2 d$ & $9.87 \pm 0.34 a$ & $1.14 \pm 0.06 a$ & $1118 \pm 44 a$ \\
\hline 30Apr. & $101 \pm 3 a b$ & $695 \pm 6 a$ & $11.9 \pm 0.3 c$ & $51.4 \pm 0.8 \mathrm{c}$ & $28.9 \pm 0.3 c$ & $120 \pm 2 c$ & $9.56 \pm 0.24 a$ & $1.13 \pm 0.03 a$ & $1148 \pm 24 a$ \\
\hline 10May. & $90 \pm 2 c$ & $698 \pm 10 a$ & $13.2 \pm 0.1 b$ & $48.3 \pm 0.7 d$ & $26.4 \pm 0.3 d$ & $132 \pm 2 b$ & $7.86 \pm 0.25 \mathrm{c}$ & $1.04 \pm 0.03 b$ & $1034 \pm 33 b$ \\
\hline 20May. & $85 \pm 2 d$ & $696 \pm 5 a$ & $14.4 \pm 0.2 \mathrm{a}$ & $45.1 \pm 0.7 e$ & $23.7 \pm 1.0 \mathrm{e}$ & $145 \pm 3 a$ & $6.39 \pm 0.12 d$ & $0.92 \pm 0.03 a$ & $929 \pm 13 c$ \\
\hline$F$-value & 38.38 & 0.24 & 134.27 & 111.06 & 18.59 & 135.03 & 93.62 & 231.14 & 43.40 \\
\hline$P$-value & $<0.001$ & 0.939 & $<0.001$ & $<0.001$ & $<0.001$ & $<0.001$ & $<0.001$ & $<0.001$ & $<0.001$ \\
\hline Sig. & ** & ns & ** & ** & ** & ** & ** & ** & ** \\
\hline
\end{tabular}

Data are means \pm standard deviation $(n=4)$. Different lowercase letters indicate significantly differences in each column, respectively. 
Experiment 2: Comparation of mean agronomic characteristics, forage quality and yield under soil regimes and seeding rates in summer-sown in 2017.

\begin{tabular}{|c|c|c|c|c|c|c|c|c|c|}
\hline \multirow[t]{3}{*}{ Treatments } & \multicolumn{2}{|c|}{ Agronomic characteristics } & \multicolumn{4}{|c|}{ Forage qualities } & \multicolumn{3}{|l|}{ Yields } \\
\hline & $\mathrm{PH}$ & TD & $\mathrm{CP}$ & NDF & ADF & RFV & DW yield & $\mathrm{CP}$ yield & RFV yield \\
\hline & $(\mathrm{cm})$ & $\left(\right.$ No. $\left./ m^{2}\right)$ & $(\%)$ & $(\%)$ & $(\%)$ & & $\left(\right.$ t ha $\left.^{-1}\right)$ & $\left(\right.$ t ha $\left.^{-1}\right)$ & $\left(\mathrm{ha}^{-1}\right)$ \\
\hline \multicolumn{10}{|l|}{ Soil regimes } \\
\hline No-tillage & $84 \pm 1 a$ & $473 \pm 15 a$ & $11.1 \pm 0.2 a$ & $54.8 \pm 0.9 a$ & $32.2 \pm 0.4 a$ & $108 \pm 2 a$ & $6.70 \pm 0.37 a$ & $0.75 \pm 0.05 a$ & $726 \pm 49 a$ \\
\hline Tillage & $84 \pm 2 a$ & $467 \pm 12 a$ & $11.2 \pm 0.2 \mathrm{a}$ & $54.6 \pm 0.4 a$ & $31.9 \pm 0.4 a$ & $109 \pm 1 a$ & $6.66 \pm 0.19 a$ & $0.75 \pm 0.02 a$ & $727 \pm 24 a$ \\
\hline \multicolumn{10}{|c|}{ Seeding rates } \\
\hline $210 \mathrm{~kg} / \mathrm{ha}$ & $85 \pm 2 a$ & $460 \pm 11 b$ & $11.1 \pm 0.2 b$ & $54.9 \pm 0.7 a$ & $32.2 \pm 0.4 a$ & $108 \pm 1 b$ & $6.41 \pm 0.21 c$ & $0.71 \pm 0.03 \mathrm{c}$ & $694 \pm 29 c$ \\
\hline $225 \mathrm{~kg} / \mathrm{ha}$ & $84 \pm 1 a$ & $469 \pm 10 b$ & $11.1 \pm 0.2 \mathrm{ab}$ & $55.0 \pm 0.5 a$ & $32.0 \pm 0.5 \mathrm{a}$ & $108 \pm 2 b$ & $6.68 \pm 0.13 b$ & $0.74 \pm 0.02 b$ & $723 \pm 18 b$ \\
\hline $240 \mathrm{~kg} / \mathrm{ha}$ & $85 \pm 2 a$ & $481 \pm 11 a$ & $11.3 \pm 0.1 \mathrm{a}$ & $54.2 \pm 0.7 \mathrm{~b}$ & $31.9 \pm 0.3 a$ & $110 \pm 1 a$ & $6.95 \pm 0.21 a$ & $0.78 \pm 0.03 a$ & $764 \pm 26 a$ \\
\hline
\end{tabular}

Note: Data are means \pm standard deviation ( $n=12$ for soil regime, $n=8$ for seeding rate). PH, plant height; TD, Tiller density; CP, crude protein; NDF, Neutral detergent fiber; ADF, Acid detergent fiber; RFV, relative feed value. Different lowercase letters indicate significantly differences at $p<0.05$ in each column under soil regime or seeding rate, respectively.

\section{Table 5}

Effects of sowing regimes on dry weight (DW) yield, crude protein (CP) yield, relative feed value (RFV) yield, growing days, water use efficiency (WUE), N fertilizer use efficiency (FUE), gross income (GI) and Net income (NI) across three growing seasons of 2017-2019.

\begin{tabular}{|c|c|c|c|c|c|c|c|c|c|c|c|c|c|c|c|c|c|}
\hline \multirow[t]{3}{*}{ Year } & \multirow{3}{*}{$\begin{array}{l}\text { Sown } \\
\text { Regimes }\end{array}$} & \multicolumn{2}{|c|}{ DW yield } & \multicolumn{2}{|l|}{ CP yield } & \multicolumn{2}{|c|}{ RFV yield } & \multicolumn{2}{|c|}{ Growing } & \multicolumn{2}{|l|}{ WUE } & \multicolumn{2}{|l|}{ FUE } & \multicolumn{2}{|l|}{$\mathrm{Gl}$} & \multicolumn{2}{|l|}{$\mathrm{NI}$} \\
\hline & & $\mathrm{tha}^{-1}$ & IP & $\mathrm{t} \mathrm{ha}^{-1}$ & IP & $\mathrm{ha}^{-1}$ & IP & Days & IP & $\mathrm{kg}$ & IP & & IP & & IP & US\$ & \\
\hline & & & $\%$ & & $\%$ & & $\%$ & & $\%$ & & $\%$ & $\begin{array}{l}\mathrm{Kg} \mathrm{kg}^{-} \\
\end{array}$ & $\%$ & $\begin{array}{l}\text { US\$ } \\
\text { ha }^{-1}\end{array}$ & $\%$ & & $\mathrm{c}$ \\
\hline \multirow[t]{2}{*}{2017} & Two & $16.98 a$ & 46.8 & $1.94 a$ & 37.1 & $1900 a$ & 63.4 & 118 & 29.7 & $86.4 a$ & 10.2 & $32.4 a$ & -4.1 & $3634 a$ & 57.0 & $2743 a$ & 4 \\
\hline & One & $11.57 \mathrm{c}$ & & $1.42 \mathrm{c}$ & & $1163 c$ & & 91 & & $78.4 b$ & & $33.7 a$ & & $2314 d$ & & $1854 d$ & \\
\hline \multirow[t]{2}{*}{2018} & Two & $14.79 b$ & 47.5 & $1.70 \mathrm{~b}$ & 43.4 & $1662 b$ & 60.8 & 119 & 65.3 & $41.9 c$ & 2.2 & $28.3 b$ & 0.35 & $2957 c$ & 72.1 & $2150 c$ & 1 \\
\hline & One & $10.02 d$ & & $1.18 \mathrm{~d}$ & & $1034 d$ & & 72 & & $40.9 c$ & & $28.2 b$ & & $1718 f$ & & $1300 f$ & \\
\hline \multirow[t]{2}{*}{2019} & Two & $14.30 \mathrm{~b}$ & 66.4 & $1.70 \mathrm{~b}$ & 66.3 & $1632 b$ & 87.6 & 120 & 31.9 & $43.5 \mathrm{c}$ & 35.6 & $28.3 b$ & 16.4 & $3274 b$ & 78.1 & $2467 b$ & ; \\
\hline & One & $8.59 \mathrm{e}$ & & $1.02 \mathrm{e}$ & & $870 e$ & & 91 & & $32.0 \mathrm{~d}$ & & $24.4 \mathrm{c}$ & & $1839 e$ & & $1420 \mathrm{e}$ & \\
\hline \multirow{3}{*}{$\begin{array}{l}P \\
\text { value }\end{array}$} & Year $(\mathrm{Y})$ & $<0.001$ & & $<0.001$ & & $<0.001$ & & & & $<0.001$ & & $<0.001$ & & $<0.001$ & & $<0.001$ & \\
\hline & $\begin{array}{l}\text { Sown } \\
\text { (S) }\end{array}$ & $<0.001$ & & $<0.001$ & & $<0.001$ & & & & $<0.001$ & & 0.034 & & $<0.001$ & & $<0.001$ & \\
\hline & $Y \times S$ & 0.057 & & 0.006 & & 0.010 & & & & $<0.001$ & & $<0.001$ & & 0.050 & & 0.038 & \\
\hline
\end{tabular}

Note: Data are means $(n=4)$. Different lowercase letters indicate significantly differences in each column, respectively. IP, increase percentage.

\section{Figures}




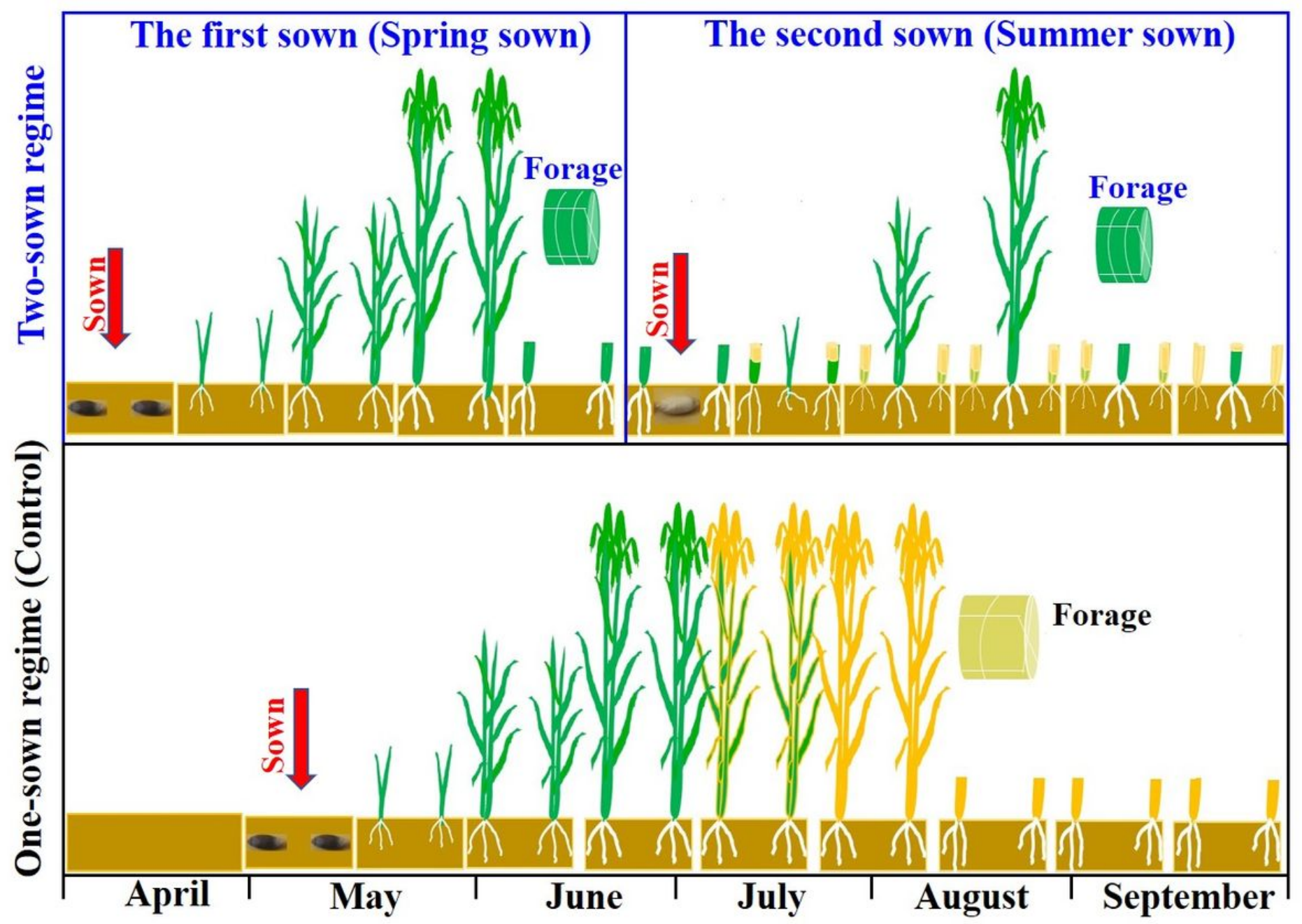

Figure 1

The diagram of two-sown regime and one-sown regime during growing season

Sowing date

Sowing date

Sowing date

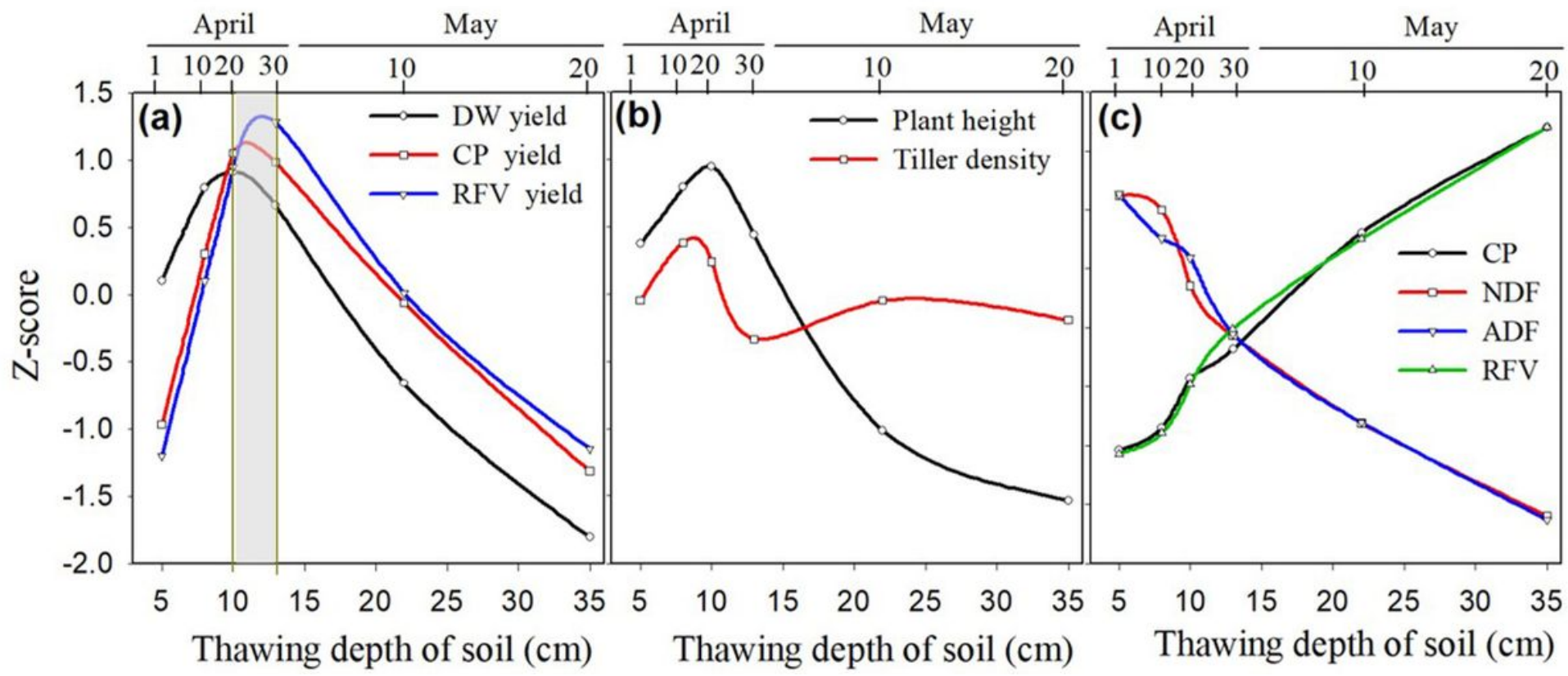




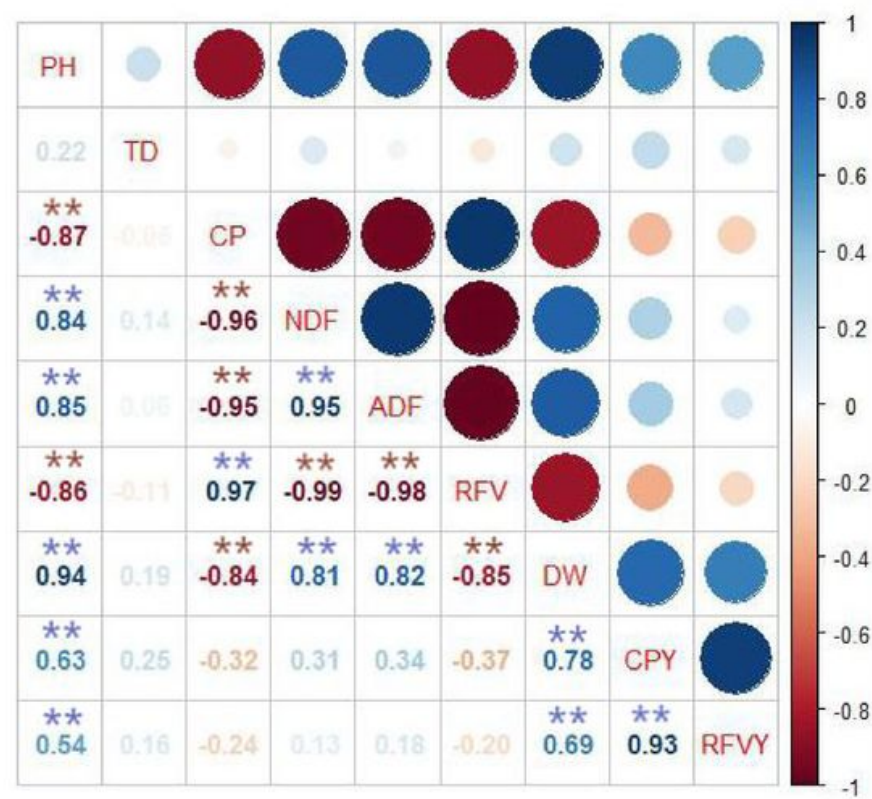

(a)

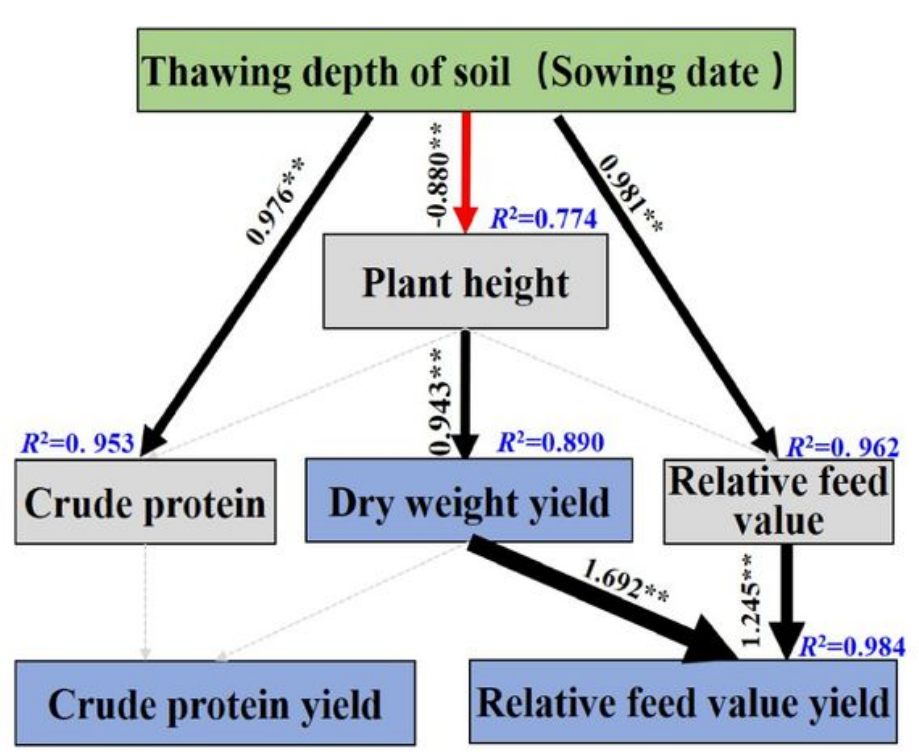

(b)

Figure 3

Experiment1: Pearson correlation coefficients (a) and structural equation models (b) among indexes of agronomic characters, forage quality and yield under spring-sown $(n=24)$. Values associated with single-headed arrows are the direct path coefficients. * and $* *$ indicate significant difference at $P<0.05$ and $P<$ 0.01 , respectively. $\mathrm{PH}$, plant height; TD, Tiller density; CP, crude protein; NDF, Neutral detergent fiber; ADF, Acid detergent fiber; RFV, relative feed value.

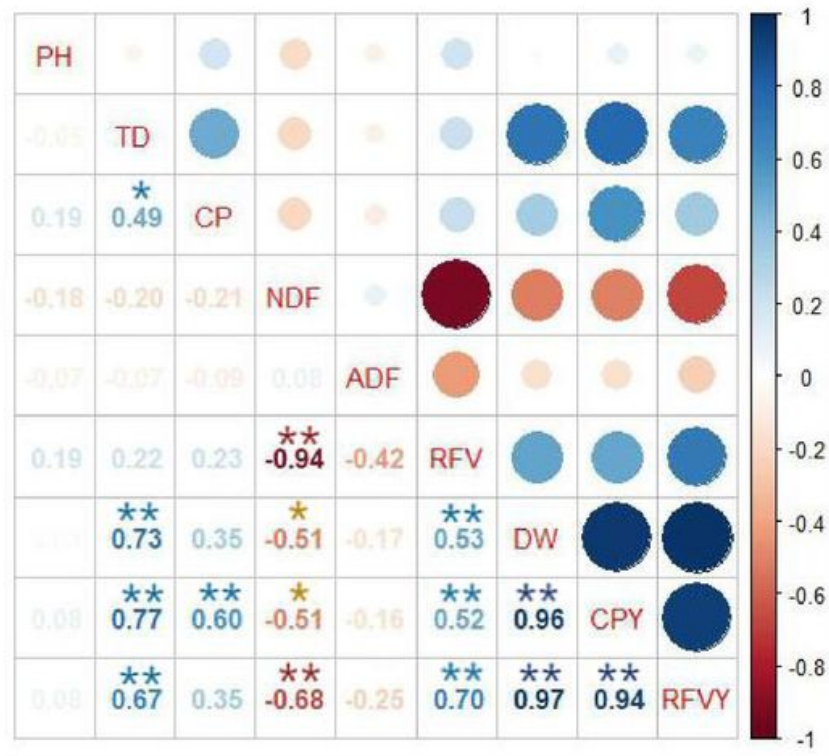

(a)

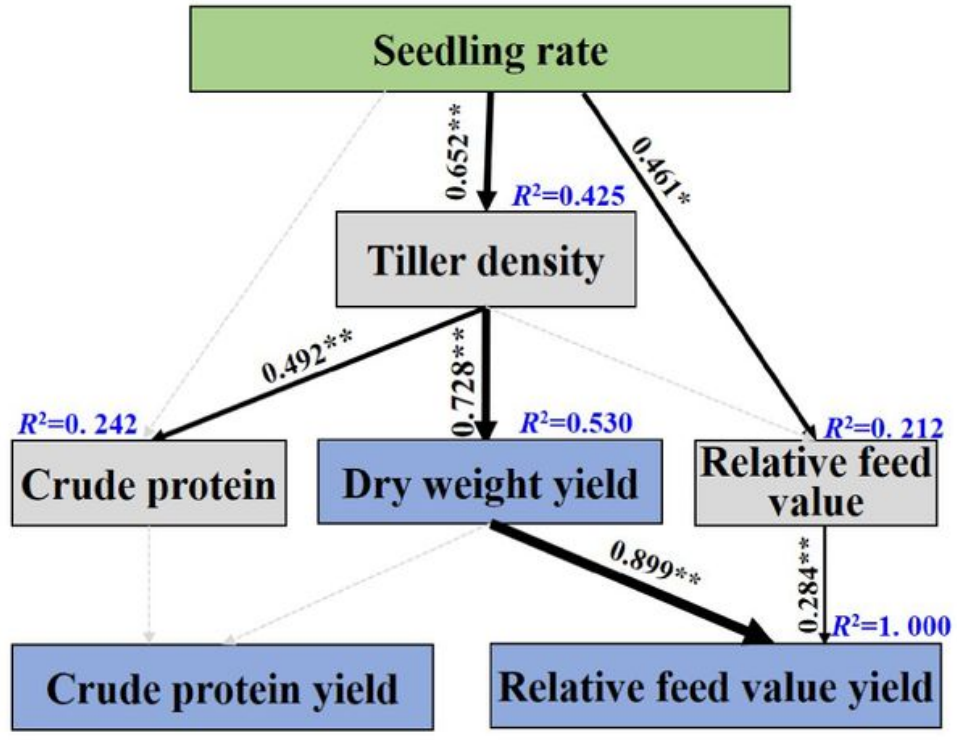

(b)

Figure 4

Experiment2: Pearson correlation coefficients (a) and structural equation models (b) among indexes of agronomic characters, forage quality and yield under summer-sown $(n=24)$. Values associated with single-headed arrows are the direct path coefficients. * and ** indicate significant difference at $P<0.05$ and $P<$ 0.01 , respectively. $\mathrm{PH}$, plant height; TD, Tiller density; CP, crude protein; NDF, Neutral detergent fiber; ADF, Acid detergent fiber; RFV, relative feed value. DW, dry weight yield; CPY, Crude protein yield; RFVY, relative feed value yield.

\section{Supplementary Files}

This is a list of supplementary files associated with this preprint. Click to download. 
- ESM1.doc

Page 14/14 